\title{
Measuring large topographic change with InSAR: lava thicknesses, extrusion rate and subsidence rate at Santiaguito volcano, Guatemala
}

Article

Accepted Version

Ebmeier, S.K., Biggs, J., Mather, T.A., Elliott, J.R., Wadge, G. and Amelung, F. (2012) Measuring large topographic change with InSAR: lava thicknesses, extrusion rate and subsidence rate at Santiaguito volcano, Guatemala. Earth and Planetary Science Letters, 335-336. pp. 216-225. ISSN 0012-821X doi: https://doi.org/10.1016/j.epsl.2012.04.027 Available at https://centaur.reading.ac.uk/34473/

It is advisable to refer to the publisher's version if you intend to cite from the work. See Guidance on citing.

To link to this article DOI: http://dx.doi.org/10.1016/j.epsl.2012.04.027

Publisher: Elsevier

All outputs in CentAUR are protected by Intellectual Property Rights law, including copyright law. Copyright and IPR is retained by the creators or other copyright holders. Terms and conditions for use of this material are defined in the End User Agreement. 


\section{www.reading.ac.uk/centaur}

\section{CentAUR}

Central Archive at the University of Reading

Reading's research outputs online 


\title{
Measuring large topographic change with InSAR: lava thicknesses, extrusion rate and subsidence rate at Santiaguito Volcano, Guatemala
}

\author{
S. K. Ebmeier ${ }^{\mathrm{a}}$, J. Biggs ${ }^{\mathrm{b}}$, T. A. Mather ${ }^{\mathrm{a}}$, J. R. Elliott ${ }^{\mathrm{a}}$, G. Wadge $^{\mathrm{c}}$, F. \\ Amelung ${ }^{d}$ \\ ${ }^{a}$ COMET+, Department of Earth Sciences, University of Oxford, UK. \\ ${ }^{b}$ COMET+, Department of Earth Sciences, University of Bristol, UK. \\ ${ }^{c}$ COMET+, NCEO, University of Reading, UK. \\ ${ }^{d}$ RSMAS, University of Miami, Florida, USA.
}

\section{Abstract}

Lava flows can produce changes in topography on the order of 10s-100s of metres. A knowledge of the resulting volume change provides evidence about the dynamics of an eruption. Using differential InSAR phase delays, it is possible to estimate height differences between the current topography and a Digital Elevation Model (DEM). This does not require a pre-event SAR image, so it does not rely on interferometric phase remaining coherent during eruption and emplacement. Synthetic tests predict that we can estimate lava thickness of as little as $\sim 9 \mathrm{~m}$, given a minimum of 5 interferograms with suitably large orbital baseline separations. In the case of continuous motion, such as lava flow subsidence, we invert interferometric phase simultaneously for topographic change and displacement. We apply this to Santiaguito volcano, Guatemala, and measure increases in lava thickness of up to $140 \mathrm{~m}$ between 2000 and 2009, largely associated with activity between 2000 and 2005. We find a mean extrusion rate of $0.43+/-0.06 \mathrm{~m}^{3} / \mathrm{s}$, which lies within 
the error bounds of the longer term extrusion rate between 1922-2000. The thickest and youngest parts of the flow deposit were shown to be subsiding at an average rate of $\sim-6 \mathrm{~cm} / \mathrm{yr}$. This is the first time that flow thickness and subsidence have been measured simultaneously. We expect this approach to be suitable for measurement of landslides and other mass flow deposits as well as lava flows.

Keywords: InSAR, volcano, Santiaguito, SRTM, DEM, lava flow, lava thickness

\section{Introduction}

2 Measurements of lava volume flux at erupting volcanoes are important 3 both as evidence of the processes driving an eruption, and for monitoring 4 the development of young lava flows and associated hazard. The volume 5 flux of lava at a volcano can provide important evidence about source depth 6 or conduit dimensions (Harris et al., 2007), and therefore constrain models 7 of the magma dynamics driving an eruption. Comparison of current time8 averaged effusion rates to past rates derived from field measurements can 9 give us insight into long-term trends in volcanic behaviour (e.g. Siswowidjoyo 10 et al. (1995)) and to distinguish between increasing and decreasing levels of activity within long-duration eruptions (Wadge, 1981; Harris, 2000). Lava extrusion rate (or effusion rate for less viscous magmas) is also a primary control on the shape, pattern of growth, cooling rate and morphology of 14 a lava field (Rowland and Walker, 1990; Pinkerton and Wilson, 1994) and hazard. 
Interferometric Synthetic Aperture Radar (InSAR) measures the phase change between time separated radar images. Geometric phase contributions are corrected during the construction of interferograms using satellite orbit information and Digital Elevation Models (DEMs). Where the DEM used in processing differs from the topography at the time when InSAR data is acquired, phase contributions originating in the difference in topography (generally referred to as 'DEM errors'), remain in the interferograms. Since InSAR is most commonly used to measure millimetre- to centimetre-scale deformation, these topographic phase shifts are generally treated as nuisance factors and corrected (e.g. Berardino et al. (2002); Samsonov et al. (2011)). In this paper we present an application for estimating topographic changes on the order of 10s to 100s of metres, using a set of Interferometric Synthetic Aperture Radar (InSAR) images. We run synthetic tests to determine limitations, uncertainties and data requirements, and measure change in lava thickness, long-term extrusion rate (Section 4) and flow shape (Section 5) at Santiaguito volcano, Guatemala, between 2000 and 2009. We also solve simultaneously for lava subsidence during our period of InSAR data acquisitions (Section 6). Finally, we discuss the usefulness of this method as a tool for volcanologists.

\subsection{Background: Measurements of lava extrusion rate}

Time-averaged lava extrusion rates are commonly estimated using either satellite (e.g. Harris et al. (2011)) or ground-based (e.g. Ryan et al. (2010) ) remote sensing methods since they allow a complete flow-field to be measured simultaneously and can be repeated at long intervals. In contrast, field measurements capture instantaneous fluxes that may not be representative 
of overall lava flux and rely on potentially dangerous measurements of mean lava velocity and channel dimensions (e.g. Calvari (2003)) and are less suited to long-term extrapolation (discussed in detail by Wright et al. (2001)).

Remote sensing measurement of lava flux, both ground- and satellitebased, falls into two categories: 1) thermal methods (e.g. as at Stromboli (Calvari et al., 2010), Kilauea (Harris et al., 1998) or Unzen (Wooster and Kaneko, 1998)) and 2) volumetric methods (e.g. at Okmok (Lu et al., 2003), Etna (Stevens et al., 2001) or Arenal (Wadge et al., 2006)). Thermal methods (discussed in detail by Harris et al. (2007)) use heat flux models to calculate lava mass fluxes. This relies on there being a linear relationship between heat flux and lava flow area, a reasonable assumption where flow area is controlled by cooling, but not where it is limited by topographic features (Harris et al., 2007). Volumetric methods involve differencing digital elevation models (DEMs), which can be constructed from topographic maps (e.g. Wadge et al. (2006)), field measurements (e.g. Sparks et al. (1998)), aerial/satellite laser altimetry (e.g. Garvin (1996)), ground-based radar (e.g. Macfarlane et al. (2006)) or satellite optical/radar data (Lu et al., 2003). Volumetric estimates of effusion rates will be underestimates where material has been removed by erosion between measurements of topography.

Routinely acquired satellite data can produce a greater temporal frequency of measurements than could be achieved from ground based campaigns. However, two primary limitations apply to the use of satellite data to estimate lava effusion rate: cloud/water vapour cover and acquisition geometry. Infrared imagery (e.g. ASTER/MODIS) cannot be used where the site of interest is cloud covered. Coppola et al. (2010)'s comparison of ground 
Figure 1: a) Santa Maria volcano and Santiaguito lava dome, Guatemala. Lavas and other eruptive products from the growth of Santiaguito between 1922 and 2006 are marked schematically, after Escobar Wolf et al. (2008). b) Schematic showing variations in extrusion rate at Santiaguito between 1920 and 2010. Extrusion rates are from Harris et al. (2007); Rose $(1972,1987)$ and show time-averaged, rather than instantaneous rates.

Figure 2: Illustration of criteria for identifying DEM artefacts. a) Map of the correlation coefficient squared $\left(\mathrm{R}^{2}\right)$ of the correlation coefficient between phase and baseline. b) Map of the lower limit of the $95 \%$ confidence interval for correlation coefficient (R). c) Map of the lower limit of gradient of phase with respect to baseline $\left(\frac{\delta \phi}{B_{\text {perp }}}-\sigma_{\frac{\delta \phi}{B_{\text {perp }}}}\right)$. d) Example of $\frac{\delta \phi}{B_{\text {perp }}}$ relationship where there is a significant difference between the DEM and current topography. e) Example of an area of smaller topographic change where the $\frac{\delta \phi}{B_{\text {perp }}}$ relationship is still robust and f) Illustration of relationship between $\frac{\delta \phi}{B_{\text {perp }}}$ where there has been no significant topographic change between 2000 and 2007. Locations of d, e and $\mathrm{f}$ are indicated on $\mathrm{a}, \mathrm{b}$ and $\mathrm{c}$.

and satellite based thermal measurements found that $\sim 65 \%$ of MODIS imagery of Piton de la Fournaise was obscured by clouds and unusable. The construction of DEMs from satellite data generally requires a specifically designed acquisition strategy, such as the ERS1/2 tandem mission. DEMs can be constructed from pairs of radar images only where spatial separation (satellite baseline) is high and temporal separation is low. 


\subsection{Background: Santiaguito lava fields}

The Santiaguito lava dome complex (Figure 1a) has been growing persistently since 1922 in the explosion crater formed by the 1902 eruption of Santa Maria volcano. Activity since 1922 has consisted of intermittent explosions and ash plumes and the extrusion of dacitic lava flows, forming a dome complex of $\sim 1.1 \mathrm{~km}^{3}$ (Harris et al., 2002). Since 1977, activity has been centred on El Caliente vent (Figure 1) .

The average extrusion rate between 1922 and 1984, as estimated from detailed field mapping, was $0.46 \mathrm{~m}^{3} \mathrm{~s}^{-1}$ (Harris et al., 2002). Harris et al. (2002) made 18 further estimates of extrusion rate at Santiaguito between 1987 and 2000, using thermal satellite imagery. These showed a cyclical pattern in extrusion with a short (3-6 years) burst of high rate extrusion, followed by a longer period (3-11 years) at a lower rate, but with an overall decay in extrusion rate between 1922 and 2000 (Figure 1b). Instantaneous extrusion rate increased from $0.6 \mathrm{~m}^{3} \mathrm{~s}^{-1}$ in 2000 to $1.4 \mathrm{~m}^{3} \mathrm{~s}^{-1}$ in 2002 , the highest measurement of extrusion at Santiaguito since 1963 (these short-lived rates greatly exceed the time averaged values shown in Figure 1b). Such high rates are short-lived and are likely to be missed by time-averaged eruption rate estimates. Activity at Santiaguito has changed from endogenous, where the dome grows by the subsurface accumulation of magma (1922-1929), through a period of transition (1929-1958) to exogenous (1958 onwards) behaviour, where lava is extruded onto the ground surface. Flow length has also increased due to decreasing silica content and consequently lower viscosity (Harris et al., 2002). Harris et al. (2002) suggest that these changes are indicative of magma source exhaustion and suggest that a continued decrease 
in extrusion rate, silica content and increase in duration of low flux periods might indicate that the Santiaguito lava dome eruption is drawing to a close, but later observations of higher rate extrusion in 2002 (Harris et al., 2004), and more recently in 2011-early 2012 are not in keeping with this interpretation. Santiaguito's most recent period of high extrusion rate activity has produced twin lava flows extending more than $2 \mathrm{~km}$ from El Caliente, and were advancing at more than $5 \mathrm{~m}$ per day in June 2011 (J.B. Johnson, personal communication, 2012).

\section{Method}

Interferograms include phase contributions from differences in satellite position and resulting viewing geometry. These are generally divided into a 'flat earth' correction $\left(\delta \phi_{\text {orbit }}\right)$, and a correction for the effect of viewing topography from different angle $\left(\delta \phi_{\text {topo }}\right)$. Other contributions come from changes to the distribution of tropospheric water vapour between radar acquisitions $\left(\delta \phi_{a t m}\right)$, changes to scattering properties of the ground $\left(\delta \phi_{\text {pixel }}\right)$ and ground movements $\left(\delta \phi_{\text {defo }}\right)($ e.g. Massonnet and Feigl (1998)).

$$
\delta \phi=\delta \phi_{\text {orbit }}+\delta \phi_{\text {topo }}+\delta \phi_{\text {atm }}+\delta \phi_{\text {pixel }}+\delta \phi_{\text {defo }}
$$

Phase shifts caused by topography change $\left(\delta \phi_{\text {topo }}\right)$ between the times of DEM and InSAR acquisitions exhibit a characteristic linear relationship with the perpendicular separation of satellite positions $\left(\mathrm{B}_{\text {perp }}\right)$, where the gradient depends primarily on radar wavelength $(\lambda)$, incidence angle $(\nu)$, range of satellite from the ground $(r)$ and vertical change in topography $(\delta z)$ 
(e.g. Rodriguez and Martin (1992); Zebker and Villasensor (1992); Ferretti et al. (1999)).

$$
\delta \mathrm{z}=\frac{\mathrm{r} \lambda \sin \nu}{4 \pi B_{\text {perp }}} \delta \phi_{\text {topo }}
$$

Thus, where phase change of an individual pixel can be shown to have a systematic relationship to baseline $\left(\mathrm{B}_{\text {perp }}\right)$, we assume that topographic phase contributions, $\delta \phi_{\text {topo }}$, dominate the measured phase shift, so the change in topography since the DEM was constructed can be calculated. The first step is to map out the region over which topographic change has taken place using phase-baseline relationships for a set of interferograms (described in detail in Section 3.1). The second is then to invert phase data covering that region to retrieve change in topographic height. Where deformation is expected to be negligible, this can be a single inversion. We discussion joint inversion for $\delta \phi_{\text {topo }}$ and $\delta \phi_{\text {def }}$ in Section 3.4.

Using a set of interferograms, this problem is of the form $\mathbf{d}=\mathbf{G z}$, where $\mathbf{d}$ is a column vector containing the pixel phase shift in each interferogram, $\mathbf{z}$ is the corresponding change in topographic height and $\mathbf{G}$ is a design matrix containing the corresponding set of perpendicular baselines and a constant multiplier, $\frac{r \lambda \sin \nu}{4 \pi}$. Baselines estimated for the start and end of each interferogram were interpolated linearly to find the baseline at Santiaguito, and constant values for $\nu(39.2 \mathrm{deg})$ and $\mathrm{r}(843044 \mathrm{~m})$ are used. This is reasonable as the variation in these two properties is less than a fraction of a percent, and orders of magnitude lower than the uncertainty in our phase measurements expected to be introduced by atmospheric artefacts.

We find topographic change (z) using a weighted linear least squares 
inversion:

$$
\mathbf{z}=\left[\mathbf{G}^{\mathbf{T}} \mathbf{W}_{\phi}^{-1} \mathbf{G}\right]^{-1} \mathbf{G}^{\mathbf{T}} \mathbf{W}_{\phi}^{-1} \mathbf{d}
$$

Each interferogram in the inversion is weighted according to its maximum variance $\left(\sigma_{\max }^{2}\right)$. We use a weighting matrix, $\mathbf{W}_{\phi}$, with diagonal elements of $\sigma_{\max }^{2}$ for each interferogram and off-diagonal elements of 0 , so that we neglect the effects of covariance in atmospheric noise between interferograms. The uncertainty in $\mathbf{z}\left(\sigma_{z}\right)$ is then $\frac{r \lambda \sin \nu}{4 \pi}\left[\mathbf{G}^{\mathbf{T}} \mathbf{W}_{\phi}^{-1} \mathbf{G}\right]^{-1}$.

\section{Application to Santiaguito}

Interferograms covering Santiaguito lava dome, Guatemala, were produced from ALOS data between 2009 and 2010 (Track 174, Frame 280, 7 interferograms, from 7 acquisitions). Interferograms were constructed using the Repeat Orbit Processing software (ROI_PAC) developed at Caltech/JPL (Rosen et al., 2004) with topographic correction made using NASA's Shuttle Radar Topography Mission 90 m Digital Elevation Model (DEM) (Rosen et al., 2001), which was interpolated and resampled to a spacing of $30 \mathrm{~m}$. SRTM data were acquired from single pass Interferometric Synthetic Aperture Radar (SAR) instrument on an 11 day shuttle mission in February 2000 for the specific purpose of producing a global DEM (Rosen et al., 2001). The atmospheric error typical of each interferogram is obtained from a 1D covariance model fit to the auto-covariance function of atmospheric noise in each interferogram (Hanssen, 2001; Wright, 2004). We find maximum standard deviations in the range 4-7 $\mathrm{mm}$ and typical length scales of $13-63 \mathrm{~km}$. 


\subsection{D lava flow map}

We test and apply two criteria for identifying topographic phase shifts at Santiaguito: (1) the lower confidence interval of the Pearson productmoment correlation coefficient $(\mathrm{R})$ between $\delta \phi$ and $\mathrm{B}_{\text {perp }}$ (Wonnacott, 1990) (e.g. Figure 2b) and (2) the minimum gradient as calculated from inversion formal errors, $\left(\mathbf{z}-\sigma_{z}\right)$ (e.g. Figure $\left.2 \mathrm{c}\right)$.

Although a strong correlation between $\delta \phi$ and $\mathrm{B}_{\text {perp }}$ is reflected by a high value for the coefficient of determination $\left(R^{2}\right)$, this may be due either to a topographic phase shift or simply consistently low phase values across all baselines. Using the lower limits of the $95 \%$ confidence interval for the correlation coefficient, however, allows us to distinguish between these two cases (compare Figures $2 \mathrm{a}$ and $2 \mathrm{~b}$ ). The boundary where the lower limit of the correlation coefficient falls below 0 (or rises above 0 when considering a decrease in topographic height), captures the extent of a region of topographic change and can be extracted from phase data using a mask. Similarly, where the minimum value for phase-baseline gradient falls below 0 , there is no demonstrable relationship between $\delta \phi$ and $\mathrm{B}_{\text {perp }}$ and therefore no significant topographic change. We find this method (criterion (2)) slightly more useful with the Santiaguito data, as the use of the lower confidence interval for $\mathrm{R}$ occasionally returns false positives (as can be seen on Figure $2 \mathrm{~b}$ ).

There is a good general correlation between the map outline of the ALOS determined thickness changes found here, the field mapping of the lava flows (Escobar Wolf et al., 2008) extruded between 2000 and 2006 (Figure 3c) and an ASTER image from from February 2009 (Figure 3b). Santiaguito's topography did not change significantly during the time when SAR data were 
Figure 3: a) Example of an interferogram showing topographic phase shifts at Santiaguito lava dome, Guatemala (14th June 2009 - 14th September 2009, perpendicular baseline $=-233 \mathrm{~m}$.$) Azimuth (\mathrm{Az})$ and incidence angle $(\sim 39 \mathrm{deg})$ directions are indicated. b) ASTER multispectral image at 15 metre resolution from $7^{\text {th }}$ February 2009 (Red, green and near infrared bands) with colours inverted and saturation increased, to make lava flows clearer. c) Schematic map of lava flows from El Caliente vent at Santiaguito, after Escobar Wolf et al. (2008). Flows emplaced after the SRTM data were acquired in 2000 are coloured red. d) Map of lava thicknesses calculated from phase shifts in our complete set of interferograms over Santiaguito.

acquired (2007-2010). The last extrusive period to affect our coherent region at Santiaguito ended in 2005 (Escobar Wolf et al. (2008) and Smithsonian database) and we assume that topographic changes due to weathering, rockfall and ash deposition are below the sensitivity of our measurements.

We expect the spatial resolution of our data to be the same as the DEM used in processing $(90 \mathrm{~m})$, and that we can deduce the shape of the deposit from our $\left(\mathbf{z}-\sigma_{z}\right)$ maps to a precision of about two pixels $(180 \mathrm{~m})$ around its edges. We are unable to capture the complete lava flow map at Santiaguito due to phase incoherence. Where the scattering properties of the ground change rapidly, the radar phase returned from the ground alters between satellite acquisitions in an unpredictable way so that shifts caused by topographic change or deformation are not retrievable. Incoherence in the area around El Caliente vent is presumably caused by changes in scatterer properties due to minor explosive eruptions and rockfall deposits from dome activity. 
Figure 4: a) Profile along lava flow showing new material over original SRTM surface. b, c, d and e show cross sectional profiles of the lava flow thickness. The SRTM topographic surface is shown by a solid black line, while the young lava is shown in solid grey. Cross section locations are shown on the inset to Figure 4a.

\subsection{Lava volume and effusion rate}

We find a maximum lava thickness of $\sim 140 \mathrm{~m}$ at the closest measurable point to the active vent. Lava thickness decreases with distance from the vent, with some individual flow units clearly identifiable in the structure (Figure 3d and 4a-e). We estimate flow-field volume by integrating the height increase across all pixels on the surface of the lava flow and find a total increase in volume of $1.20 \times 10^{8} \mathrm{~m}^{3}$ between 2000 and 2009. Uncertainty in calculations of volume will depend on the accuracy with which we can resolve the edge of the deposit and estimate the surface area it covers. At Santiaguito, the lava flow perimeter is $\sim 8 \mathrm{~km}$ long giving an estimated area error of $\sim 1.4 \mathrm{~km}^{2}$. In combination with our uncertainties for lava thickness, this gives us a total uncertainty in volume change between 2000 and 2009 of the order of $1 \times 10^{7} \mathrm{~m}^{3}$, of $10 \%$.

The mean rate of change in volume between 2000 and 2009 is therefore $0.43 \pm 0.06 \mathrm{~m}^{3} / \mathrm{s}$, very close to the time averaged rate (1922-2000) of 0.44 $\pm 0.01 \mathrm{~m}^{3} / \mathrm{s}$, calculated by Harris et al. (2002). Over our area of measurement, this rate actually reflects periods of high rate lava extrusion between 2000 and 2005 and then a lack of significant extrusive activity between 2005 and 2009. We estimate volume flux during this more active period to be 0.78 
$\mathrm{m}^{3} / \mathrm{s}$. This is slightly higher than the extrusion rate measured by Durst (2006) $\left(\sim 0.68 \mathrm{~m}^{3} / \mathrm{s}\right)$ using analysis of ASTER DEMs from 2002 and 2005, and is comparable to past periods of high extrusion (Harris et al., 2002).

It is, however, likely to be an underestimate of the total flow rate over this time, as we do not have data for the complete lava flow field from 2000-2009. This is partially due to incoherence, but we are also unable to take account of the volume of any material eroded between 2000 and 2009 (unlike the thermally derived fluxes). Harris et al. (2002) suggested that extrusion rates calculated from pre-1980 field measurements underestimate the lava flux at Santiaguito between 1922 and 1987 by 5-25\%, from estimations of eroded volumes from a debris fan downstream of the volcano. If our rate is a similar underestimate, then mean extrusion rates could be as high as $0.45-0.54 \mathrm{~m}^{3} / \mathrm{s}$ from 2000 to 2009.

\subsection{Flow morphology}

We are able to examine large-scale lava flow morphology at Santiaguito using profiles through our lava thickness maps superimposed on the original 2000 DEM. The SRTM data were acquired in February 2000 during a period of extrusion that started in July 1999. The morphology of a central channel flanked by levees was already established by this time and appears as a shallow 'ridge' in the SRTM DEM (Figure 4). Subsequent viscous, dacitic lavas followed this channel in 2001-2002, 2003 and 2004, gradually increasing the height of channel, levees and banks and increasing the lava flow's aspect ratio.

Profiles A, B and C on Figure 4 (b-d) cut across part of the lava field identified as 'channelised' by Harris et al. (2004) using satellite thermal im- 
agery and synchronised field observations in 2000, 2001 and 2002. We see no evidence of the stable channel and levee structures seen by Harris et al. (2002), which are also visible in recent ASTER imagery (Figure 3b) in the older parts of the lava flows (Figure 3c). This is presumably because the levee width (68 $\pm 25 \mathrm{~m}$ measured in 2002 (Harris et al., 2004)) is below the resolution of the SRTM DEM ( $90 \mathrm{~m}$, oversampled to $30 \mathrm{~m}$ for InSAR processing). Thus the ridges represented by the SRTM data in Figure 4 are interpreted as channelised lava flows (as of February 2000) that continued to be used by subsequent flows, though the channel/levee structure is smoothed out in these data. Profile D (Figure 4e) is from the zone of dispersed flow and has a lower aspect ratio. The limiting factor for measuring flow morphology from interferogram-derived topographic change is the resolution of the DEM used in interferogram construction.

\subsection{Lava flow subsidence}

Channelised lava may continue to flow as it cools and after its source flux has stopped, resulting in advancement of the flow toe, a fall in the level of lava in the channel, and potentially the sinking or even collapse of any bridging crust across the channel (e.g. Borgia et al. (1983)). Such processes are expected to result in deformation soon after flow emplacement of a magnitude too large to detect with differential InSAR (several metres, see Figure 7b). As our data covers a period 3-5 years after the most recent flows at Santiaguito were emplaced, we expect our measurements to capture deformation associated with contraction and compaction, rather than flow processes. 
After flow has ceased, the subsidence of lava may be caused by thermal contraction (Peck, 1978) or by mechanical processes, such as the rearrangement of clasts (Stevens et al., 2001). Reported InSAR measurements of lava subsidence range in magnitude from $0.8 \mathrm{~cm} / \mathrm{yr}$ at Etna to $\sim 83 \mathrm{~cm} / \mathrm{yr}$ at Okmok (Toombs and Wagde, in review) with a few $\mathrm{cm} / \mathrm{yr}$ being typical. Most lava subsidence measurements to date have been made at basaltic, low viscosity flows (Table 1, Figure 6). Rates are often constant by the time surfaces become coherent enough to measure using InSAR. We expect lava flows as young as those at Santiaguito to still be subsiding, as InSAR observations of lava flows at Etna and Okmok volcanoes have measured subsidence $\sim 10$ and 35 years after emplacement, respectively (Stevens et al., 2001; Lu et al., 2005a).

We solve simultaneously for change in lava thickness and for deformation, weighting our interferograms on the basis of atmospheric noise as described in Section 3 (Figure 5a). We use a linear least squares inversion of interferogram phase to find velocities between acquisition dates (e.g. Berardino et al. (2002)), using a generalised inverse matrix (Moore-Penrose pseudoinverse) found from singular value decomposition. We solve for velocities relative to the first acquisition date, where we assume that there is no ground motion. This allows us to construct subsidence time series (e.g. Figure 5e). As the design matrix for such a joint inversion is rank deficient, we use a finite difference approximation of the second differential of the time series as a smoothing constraint. We use zero value constraints for the first and last dates in the time series. As we expect subsidence to be linear, we overweight the smoothing parameter. 
We investigate the trade-off between our uncertainties in lava thickness and subsidence rate using a Monte Carlo approach, where we add randomly generated, spatially correlated noise (as described in Section 3) before performing the joint inversion and repeated for 100 perturbed datasets. This showed a positive trade-off between lava thickness and subsidence rate. We are therefore conservative in making estimations of uncertainty in lava subsidence. The error in lava thickness from our single inversion $( \pm 9 \mathrm{~m})$ will result in phase shifts of between -0.03 and 0.48 radians in the individual Santiaguito interferograms and an apparent subsidence rate of magnitude \pm $2 \mathrm{~cm} / \mathrm{yr}$. We do not expect to be able to detect subsidence below this rate.

Both joint inversion and correction of phase from single inversion result in similar trends in subsidence rate measurements. We measure the largest subsidence rates (6-10 $\pm 2 \mathrm{~cm} / \mathrm{yr}$ in satellite line of sight) at the thickest, youngest part of the flow (Figure $5 \mathrm{a}, \mathrm{b}, \mathrm{d}, \mathrm{e}$ ). In this part of the field the most recent lava flows were only 5 years old (from 2004) at the time our first SAR data acquisition, and total thickness of lava emplaced lies between $\sim 90$ and $140 \mathrm{~m}$. Thinner, older parts of the flow show no deformation above a rate of $\sim 2 \mathrm{~cm} / \mathrm{yr}$, except for an area on the edge of the 2001-2002 flow (Figure 5a and b).

We expect the subsidence rate of young lava to depend on its age, thickness, composition and the morphology of the underlying substrate. As measurements across most of the lava field are below the bounds of our expected uncertainty, we lack the data to distinguish between these possibilities. However, a plot of lava subsidence against thickness does show some positive correlation, with a higher gradient at thicknesses above about $100 \mathrm{~m}$, where 
the lava flows are youngest (gradient $=0.04 \mathrm{~cm} / \mathrm{yr} / \mathrm{m}, \mathrm{R}^{2}=0.77$, Figure $5 \mathrm{c}$ ). Although the general correlation between these two parameters ac cross the whole lava field may reflect the trade-off between them, this change in gradient suggests a difference in behaviour between the post-2004 and older lavas (Figure 5a,b,c,d)]. Similar positive correlations between flow thickness and subsidence rate have been measured for basaltic flows (Lu et al., 2005b; Stevens et al., 2001). Without a knowledge of flow temperature structure or data allowing us to map the temporal development of subsidence rate, we are unable to distinguish between subsidence mechanisms. However, in addition to the thermal contraction expected for such a young flow, some degree of clast repacking/gravity-driven compaction seems likely, given the steepness of the slope upon which this flow was extruded (Figure 5d).

Although we expect highly viscous and thermally insulated flows such as Santiaguito to subside more slowly than less viscous basalts, the rather limited set of global measurements show no evidence of this (Figure 6). Our subsidence rate at Santiaguito adds to a very small set of observations of lava subsidence at andesitic-dacitic volcanoes (Table 1).

\section{Discussion}

Our measurements of lava thicknesses at Santiaguito demonstrate an approach suitable for monitoring extrusion and volume changes at remote or inaccessible volcanoes. We make the first measurement of volume flux at Santiaguito since extrusion of the 2004-2005 lava flows and the first observation of lava subsidence at this volcano. Our measurement of $0.43 \pm 0.06 \mathrm{~m}^{3} / \mathrm{s}$ between 2000 and 2009 should be treated as a minimum value for extrusion 
Figure 5: (a) Map of subsidence rate found from joint inversion. The apparently reduced are of the subsiding flow-field retrieved by joint inversion is a consequence of higher formal errors in lava thickness. (b) Schematic map showing the relative ages of lava flows emplaced after 2000, after Escobar Wolf et al. (2008) (c) Scatterplot of subsidence rate against lava thickness, showing an apparent linear relationship between increasing lava thickness and subsidence rate. (d) Profile of young lava laid over the original SRTM DEM (as in Figure 3). The size and direction of the arrow shows subsidence rate in satellite line of sight obtained from joint inversion. Inset panel below shows variation in subsidence rate with distance from El Caliente vent. Red dotted lines indicate the range of error in subsidence rate expected from an error in lava thickness of $\pm 9 \mathrm{~m}$. (e) Time series showing cumulative deformation in the satellite line of sight at the thickest part of the lava flow $(\sim 140 \mathrm{~m})$. Location of time series (e) is marked on $\mathrm{d}$.

Figure 6: Lava subsidence rates normalised by maximum lava thickness (Table 1) are shown as a function of the age of the lava at the time of InSAR measurement. Basaltic lavas are shown in blue, andesites in red and our result for the dacitic lava of Santiaguito in black. Numbers in brackets refer to year of lava flow emplacement. 
rate. This minimum rate is close to the long term average extrusion rate (1922-2000). Lava extrusion since 2000 has remained cyclical, with periods of high extrusion in 2000-2005 and 2011- early 2012 (J.B. Johnson, personal communication, 2012). There is no evidence in Santiaguito's flux estimates to indicate exhaustion of its magmatic source.

The ability to make combined measurements of lava flow thickness and subsidence rate may be a powerful tool for studying post-emplacement flow deformation. Where lava subsidence is higher rate or more widespread than at Santiaguito, the relationship between these two parameters could allow us to distinguish between thermal and mechanical contraction. The measurement of lava subsidence in addition to lava thickness would also be aided by a larger dataset and therefore longer time series than is available at Santiaguito.

\subsection{Method Applicability and Synthetic tests}

We expect uncertainties to be introduced to our measurements of height change by (1) errors in the DEM used in processing ( $\sim 7 \mathrm{~m}$ for SRTM, (Rosen et al., 2001)), (2) surface displacement (see Section 3.4) and (3) variations in tropospheric water vapour. The effects of (1) will be systematic, while (2) and (3) may be random, increasing the scatter in the $\frac{\delta \phi}{\delta B_{p e r p}}$ relationship.

For a dataset such as the one at Santiaguito (see Section 4), consisting of 7 interferograms with up to $140 \mathrm{~m}$ of height change and atmospheric noise of maximum standard deviation $6 \mathrm{~mm}$, the formal error from inversion to find $\frac{\delta \phi}{B_{\text {perp }}}$ is \pm 0.0009 radians $/ \mathrm{m}$, which corresponds to a mean uncertainty in lava thickness of $\sim \pm 9 \mathrm{~m}$.

We generate sets of synthetic interferograms and changes in topography (Supplemental Figure 1) to examine both the variability and distribution of 
uncertainties and the general limits of application for the methods described in Sections 2 and 3. We calculate the expected phase changes for synthetic lava fields of variable thickness and shape and add them to sets of randomly generated spatially correlated noise (e.g. Lohman and Simons (2005)) of the same means and standard deviations of variance and typical length scale as our interferograms for Santiaguito (Supplemental Figure 1). Residuals between the input synthetic lava field and the lava thicknesses retrieved were of a magnitude of $\sim 2 \mathrm{~m}$ for lava thicknesses greater than about $25 \mathrm{~m}$ (Figure 7). For lava thinner than $\sim 7 \mathrm{~m}$, the residuals exceed lava thickness. We use a Monte Carlo approach to find the mean percentage of the synthetic lava flows retrieved from these sets of synthetic interferograms using the method described above when we vary 1) synthetic lava thickness (100 repetitions) and 2) the number of interferograms used in the inversion (500 repetitions with normally distributed baselines of the same standard deviation, $250 \mathrm{~m}$, as the Santiaguito data). For synthetic lava fields with an average thickness of $\geq \sim 30 \mathrm{~m}$, we expect to be able to retrieve close to the complete volume of lava (Supplemental Figure 2a). Our tests suggest that a minimum of 5 interferograms are required to retrieve the complete lava field (Supplemental Figure 2b).

We expect to be able to detect topographic change in excess of $\sim 9 \mathrm{~m}$, given a minimum of 5 interferograms. For change greater than about $25 \mathrm{~m}$, we expect uncertainties to be less than $\sim 8 \%$. This will allow measurement of topographic change about an order of magnitude greater than InSAR deformation measurements, and at the upper end of what is measurable using range or azimuth offsets (Jonsson et al., 2002) (Figure 7b). 
Figure 7: (a) Magnitudes of residuals between synthetic lava field in interferograms with similar properties to Santiaguito data and thicknesses retrieved from inversion to find $\mathbf{m}$. These values provide an indication of the magnitude of the expected error for any pixel in our lava thickness maps. Expected errors exceed lava thickness below thicknesses of about $7 \mathrm{~m}$. (b) Illustration of range of topographic change measurable relative to other InSAR techniques.

\subsection{InSAR for measuring topographic change $\geq \sim 25 \mathrm{~m}$}

We have demonstrated with data from Santiaguito that topographic height change can be extracted from sets of interferograms with sufficient accuracy to be a useful tool for volcanologists. It is well-suited to measuring systems where changes are large, and are followed by a period of quiescence when interferograms can be constructed. This could include periodically extrusive volcanic activity and possibly very thick pyroclastic and lahar deposits. Other potential applications include measuring mass wasting deposits, such as post-earthquake or hurricane landslides. It will be less useful for targets such as lava domes themselves (rather than lava flows or pyroclastic flow deposits) because the surface changes so often that no coherent signal can be retrieved.

InSAR measurements of topographic change will be most useful where other methods are limited, for example, by frequent cloud cover. The spatial coverage of routinely acquired InSAR data is potentially greater than that available from purpose designed missions for DEM production.

Given a sufficient temporal density of data it should also be possible 
to construct a time series of topographic change. Measuring a continuous emplacement process is challenging, because the emplacement of fresh material will introduce chaotic phase changes to backscattered radar, making interferograms phase incoherent and unusable. However, if small sets of interferograms can be constructed during quiescent periods, they could be used to find topographic change relative to the acquisition of the DEM used in processing, and allow us to measure variations in time averaged extrusion rate. The time intervals over which this would be possible depends on 1) the number of interferograms needed to make height change measurements and 2) the repeat time of SAR satellite acquisitions. Our tests with synthetic data suggest that a minimum of 5 interferograms (atmospheric noise of maximum standard deviation $6 \mathrm{~mm}$ and baselines with mean $=0 \mathrm{~m}$, standard deviation $=250 \mathrm{~m}$ ) are needed to be sure of capturing uniform topographic change of magnitude $\geq 25 \mathrm{~m}$. For smaller magnitude change, shorter baselines or a greater variance of atmospheric noise, more will be required. Under ideal conditions, 5 independent interferograms can be first constructed from 10 SAR data acquisitions. This would give a temporal 'bin size' of 460 days for the ALOS data used in this paper (repeat time 46 days), less than 110 days for TerraSar-X data ( $<11$ day repeat) and 120 days for the forthcoming ESA satellite, Sentinal (12 day repeat). Shorter perpendicular baselines (e.g. \pm 50 as expected for Sentinal) will make measurement of topographic change more difficult. For baseline distributions similar to the ALOS data presented here, the primary limiting factors for measuring extrusion rate at long lasting volcanic eruptions will be the relative stability of radar scatterers on the ground surface and any deformation occurring during the period of InSAR 
measurement.

\section{Summary}

We have shown that topographic change in excess of $\sim 25$ m can be measured from interferometric phase delays in a small set of interferograms and demonstrated the usefulness of such information in volcanology. At Santiaguito we measure at extrusion rate of $0.43 \pm 0.06 \mathrm{~m}^{3} / \mathrm{s}$ between 2000 and 2009, observe the changes in flow morphology over this time, and measure lava subsidence of up to $6 \mathrm{~cm} / \mathrm{yr}$ on the thickest and youngest parts of the flow. We believe that this approach will be particularly useful for volcanic activity whereby thick lava flows or pyroclastic deposits are emplaced with little warning, as no satellite image prior to emplacement is needed. The ability to measure the change in lava thickness and subsidence simultaneously is also an advantage. This technique may also have important applications for mass wasting events such as landslides.

\section{Acknowledgments}

All ALOS data were acquired through the WInSAR programme at the University of Miami. The ASTER data are distributed by the Land Processes Distributed Active Archive Center (LP DAAC), located at the U.S. Geological Survey (USGS) Earth Resources Observation and Science (EROS) Center (lpdaac.usgs.gov). This work was supported by the National Environmental Research Council through the National Centre for Earth Observation (NCEO), of which the Centre for the Observation and Modeling of Earthquakes, Volcanoes and Tectonics (COMET) is a part. SKE is supported by 
461 an NCEO studentship and JB was funded by the ESA Changing Earth Sci462 ence Network and a Rosenstiel Podoctoral Fellowship at the University of 463 Miami. We thank Hua Wang for allowing us to use his baseline interpola464 tion script to check our own estimations. We thank Jeannie Scott for useful 465 discussions about Santiaguito. 
Table 1: Summary of InSAR measurements of lava subsidence made to date. 'Age' is the interval in years between lava flow emplacement and InSAR measurement of subsidence.

\begin{tabular}{|c|c|c|c|c|c|}
\hline Volcano & $\begin{array}{l}\text { Lava compo- } \\
\text { sition }\end{array}$ & $\begin{array}{l}\text { Age } \\
\text { (years }\end{array}$ & $\begin{array}{l}\text { Max. flow } \\
\text { thickness } \\
\text { (m) }\end{array}$ & $\begin{array}{l}\text { Max. } \\
\text { subsi- } \\
\text { dence rate } \\
(\mathrm{cm} / \mathrm{yr})\end{array}$ & References \\
\hline $\begin{array}{l}\text { Krafla } \quad(1975- \\
1984)\end{array}$ & basaltic & $17-20$ & 50 & 0.6 & Sigmundsson et al. (1997) \\
\hline $\begin{array}{l}\text { Tolbachik } \\
(1975-1976)\end{array}$ & basaltic & $16-28$ & 80 & $\sim 2$ & $\begin{array}{l}\text { Pritchard and Simons (2004); } \\
\text { Fedotov et al. (1980) }\end{array}$ \\
\hline $\begin{array}{l}\text { Okmok } \quad(1945- \\
1958)\end{array}$ & basaltic & $35-38$ & $20-30$ & $\sim 1.5$ & Lu et al. (2005b) \\
\hline Okmok (1997) & basaltic & 0.1 & 50 & 83 & Lu et al. (2005b) \\
\hline Okmok (1997) & basaltic & 3 & 50 & 4 & Lu et al. (2005b) \\
\hline $\begin{array}{l}\text { Colima } \\
1999)\end{array}$ & andesitic & $3-8$ & $\begin{array}{l}30 \quad \text { (flow } \\
\text { fronts) }\end{array}$ & 1.5 & $\begin{array}{l}\text { Pinel et al. (2011); Navarro- } \\
\text { Ochoa et al. (2002); Zobin } \\
(2002)\end{array}$ \\
\hline $\begin{array}{l}\text { Santiaguito } \\
(2004-2005)\end{array}$ & dacitic & $4-6$ & 120 & 6 & this work \\
\hline $\begin{array}{l}\text { Paricutin (1943- } \\
1953)\end{array}$ & $\begin{array}{l}\text { basaltic- } \\
\text { andesite }\end{array}$ & $54-65$ & $>70$ & $4-4.5$ & Fournier et al. (2010) \\
\hline $\begin{array}{l}\text { Reventador } \\
(2005)\end{array}$ & andesitic & $3-4$ & - & $1-2$ & Mothes et al. (2008) \\
\hline $\begin{array}{ll}\text { Sierra } & \text { Negra } \\
(1979) & \end{array}$ & basaltic & $13-19$ & - & 3 & Amelung and Day (2002) \\
\hline $\begin{array}{l}\text { Lonquimay } \\
(1988-1989)\end{array}$ & andesitic & $13-21$ & 55 & 2 & $\begin{array}{l}\text { Fournier et al. (2010); } \\
\text { Naranjo et al. (1992) }\end{array}$ \\
\hline $\begin{array}{l}\text { Nyamuragira } \\
(1991-1993)\end{array}$ & basaltic & $6-11$ & - & $1-4$ & Colclough (2006) \\
\hline $\begin{array}{l}\text { Nyamuragira } \\
(1991-1993)\end{array}$ & basaltic & $\begin{array}{r}13-18 \\
25\end{array}$ & - & 0.9 & $\begin{array}{l}\text { Toombs and Wagde (in re- } \\
\text { view) }\end{array}$ \\
\hline $\begin{array}{l}\text { Nyamuragira } \\
(2004)\end{array}$ & basaltic & $2-5$ & - & 1 & $\begin{array}{l}\text { Toombs and Wagde (in re- } \\
\text { view) }\end{array}$ \\
\hline Etna (1983) & basaltic & $10-14$ & 55 & 0.8 & Stevens et al. (1999) \\
\hline Etna (1989) & basaltic & $3-4$ & 10 & 3.5 & Briole et al. (1997) \\
\hline (1991- & basaltic & $1-2$ & 96 & 25.6 & Briole et al. (1997) \\
\hline
\end{tabular}




\section{References}

Amelung, F., Day, S., 2002. InSAR observations of the 1995 Fogo, Cape Verde, eruption: Implications for the effects of collapse events upon island volcanoes. Geophysical Research Letters 29, 120000-1.

Berardino, P., Fornaro, G., Lanari, R., Sansosti, E., 2002. A new algorithm for surface deformation monitoring based on small baseline differential SAR interferograms. IEEE Transactions on Geoscience and Remote Sensing 40, 2375-2383.

Borgia, A., Linneman, S., Spencer, D.,Diego Morales, L.,Brenes Andre, J., 1983. Dynamics of lava flow fronts, Arenal Volcano, Costa Rica. Journal of Volcanology and Geothermal Research 19, 303-329.

Briole, P., Massonnet, D., Delacourt, C., 1997. Post-eruptive deformation associated with the 1986-87 and 1989 lava flows of Etna detected by radar interferometry. Geophysical Research Letters 24, 37-40.

Calvari, S., 2003. Effusion rate estimations during the 1999 summit eruption on Mount Etna, and growth of two distinct lava flow fields. Journal of Volcanology and Geothermal Research 119, 107-123.

Calvari, S., Lodato, L., Steffke, A., Cristaldi, A., Harris, A.J.L., Spampinato, L., Boschi, E., 2010. The 2007 Stromboli eruption: Event chronology and effusion rates using thermal infrared data. Journal of Geophysical Research (Solid Earth) 115, B04201. 
Colclough, S., 2006. Investigations of Nyamuragira and Nyiragongo Volcanoes (Democratic Republic of the Congo) Using InSAR, in: Fringe 2005 Workshop.

Coppola, D., James, M.R., Staudacher, T., Cigolini, C., 2010. A comparison of field- and satellite-derived thermal flux at Piton de la Fournaise: implications for the calculation of lava discharge rate. Bulletin of Volcanology $72,341-356$.

Durst, K.S., 2006. Analysis of Eruption Rates at Santiaguito, Guatemala Using ASTER and Aerial Derived Digital Elevation Models, in: American Geophysical Union, Fall Meeting 2006.

Escobar Wolf, R., Matias Gomez, R.O., Rose, W.I., 2008. Geologic Map of Santiaguito Volcano, Guatemala. Geological Society of America Digital Map and Chart Series, 8.

Fedotov, S.A., Chirkov, A.M., Gusev, N.A., Kovalev, G.N., Slezin, Y.B., 1980. The large fissure eruption in the region of Plosky Tolbachik volcano in Kamchatka, 1975 1976. Bulletin of Volcanology 43, 47-60.

Ferretti, A., Prati, C., Rocca, F., 1999. Multibaseline insar dem reconstruction: the wavelet approach. Geoscience and Remote Sensing, IEEE Transactions on $37,705-715$.

Fournier, T.J., Pritchard, M.E., Riddick, S.N., 2010. Duration, magnitude, and frequency of subaerial volcano deformation events: New results from Latin America using InSAR and a global synthesis. Geochemistry, Geophysics, Geosystems 11, 1003-+. 
Garvin, J.B., 1996. Topographic characterization and monitoring of volcanoes via airborne laser altimetry. Geological Society, London, Special Publications 110, 137-152.

Hanssen, R.F., 2001. Radar interferometry data interpretation and error analysis. Kluwer Academic Publishers .

Harris, A., 2000. Effusion rate trends at Etna and Krafla and their implications for eruptive mechanisms. Journal of Volcanology and Geothermal Research 102, 237-269.

Harris, A., Rose, W., Flynn, L., 2002. Temporal trends in lava dome extrusion at Santiaguito 1922-2000. Bulletin of Volcanology 65, 77-89.

Harris, A.J.L., Dehn, J., Calvari, S., 2007. Lava effusion rate definition and measurement: a review. Bulletin of Volcanology 70, 1-22.

Harris, A.J.L., Flynn, L.P., Keszthelyi, L., Mouginis-Mark, P.J., Rowland, S.K., Resing, J.A., 1998. Calculation of lava effusion rates from Landsat TM data. Bulletin of Volcanology 60, 52-71.

Harris, A.J.L., Flynn, L.P., Matias, O., Rose, W.I., Cornejo, J., 2004. The evolution of an active silicic lava flow field: an ETM+ perspective. Journal of Volcanology and Geothermal Research 135, 147-168.

Harris, A.J.L., Steffke, A., Calvari, S., Spampinato, L., 2011. Thirty years of satellite-dervied lava discharge rates at Etna: Implications for steady volume output. Journal of Geophysical Research 116, B08204. 
Jonsson, S., Zebker, H., Segall, P., F., A., 2002. Fault Slip Distribution of the $1999 \mathrm{Mw} 7.1$ Hector Mine, California, Earthquake, Estimated from Satellite Radar and GPS Measurements. The Bulletin of the Seismological Society of America 92, 1377-1389.

Lohman, R.B., Simons, M., 2005. Some thoughts on the use of InSAR data to constrain models of surface deformation: Noise structure and data downsampling. Geochemistry, Geophysics, Geosystems 6, Q01007.

Lu, Z., Fielding, E., Patrick, M.R., Trautwein, C.M., 2003. Estimating lava volume by precision combination of multiple baseline spaceborne and airborne interferometric synthetic aperture radar: the 1997 eruption of okmok volcano, alaska. IEEE Transactions on Geoscience and Remote Sensing 41, 1428-1436.

Lu, Z., Masterlark, T., Dzurisin, D., 2005a. Interferometric synthetic aperture radar study of Okmok volcano, Alaska, 1992-2003: Magma supply dynamics and postemplacement lava flow deformation. Journal of Geophysical Research (Solid Earth) 110, B02403.

Lu, Z., Masterlark, T., Dzurisin, D., 2005b. Interferometric synthetic aperture radar study of Okmok volcano, Alaska, 1992-2003: Magma supply dynamics and postemplacement lava flow deformation. Journal of Geophysical Research (Solid Earth) 110, B02403.

Macfarlane, D.G., Wadge, G., Robertson, D.A., James, M.R., Pinkerton, H., 2006. Use of a portable topographic mapping millimetre wave radar at an active lava flow. Geophysical Research Letters 330, L03301. 
Massonnet, D., Feigl, K.L., 1998. Radar interferometry and its application to changes in the earth's surface. Reviews of Geophysics 36, 441-500.

Mothes, P., Biggs, J., Baker, S., Hong, S., Amelung, F., Dixon, T., 2008. Survey of Volcanic Activity in Ecuador using L-band SAR., in: AGU, Fall Meeting 2008.

Naranjo, J.A., Sparks, R.S.J., Stasiuk, M.V., Moreno, H., Ablay, G.J., 1992. Morphological, structura and textural variations in the 1988-1990 andesite lava of Lonquimay Volcano, Chile. Geological Magazine 49129, 657-678.

Navarro-Ochoa, C., Gavilanes-Ruiz, J.C., Cortes-Cortes, A., 2002. Movement and emplacement of lava flows at Volcan de Colima, Mexico: November 1998 February 1999. Journal of Volcanology and Geothermal Research $117,155-167$.

Peck, D.L., 1978. Cooling and vesiculation of Alae lava lake, Hawaii. U.S. geological survey Professional Paper 935.

Pinel, V., Hooper, A., de La Cruz-Reyna, S., Reyes-Davila, G., Doin, M.P., Bascou, P., 2011. The challenging retrieval of the displacement field from InSAR data for andesitic stratovolcanoes: Case study of Popocatepetl and Colima Volcano, Mexico. Journal of Volcanology and Geothermal Research 200, 49-61.

Pinkerton, H., Wilson, L., 1994. Factors controlling the lengths of channel-fed lava flows. Bulletin of Volcanology 56, 108-120.

Pritchard, M.E., Simons, M., 2004. Surveying Volcanic Arcs with Satellite 
Radar Interferometry: The Central Andes, Kamchatka, and Beyond. GSA Today 14, 4-11.

Rodriguez, E., Martin, J.M., 1992. Theory and design of interferometric synthetic aperture radars. IEE Proceedings F: Radar and Signal Processing 139, 147-159.

Rose, W.I., 1972. Santiaguito Volcanic Dome, Guatemala. Geological Society of America Bulletin 83, 1413-1434.

Rose, W.I., 1987. The Emplacement of Silicic Domes and Lava Flows. Geological Society of America Special Paper. volume 212. chapter Volcanic activity at Santiaguito Volcano, 1976-1984. pp. 17-27.

Rosen, P., Hensley, S., Gurrola, E., Rogez, F., Chan, S., Martin, J., Rodriguez, E., 2001. Srtm c-band topographic data: quality assessments and calibration activities, in: Geoscience and Remote Sensing Symposium, 2001. IGARSS '01. IEEE 2001 International, pp. 739 -741 vol.2.

Rosen, P.A., Hensley, S., Peltzer, G., Simons, M., 2004. Updated repeat orbit interferometry package released. Eos Transactions, AGU 85.

Rowland, S.K., Walker, G.P., 1990. Pahoehoe and aa in Hawaii: volumetric flow rate controls the lava structure. Bulletin of Volcanology 52, 615-628.

Ryan, G.A., Loughlin, S.C., James, M.R., Jones, L.D., Calder, E.S., Christopher, T., Strutt, M.H., Wadge, G., 2010. Growth of the lava dome and extrusion rates at Soufrière Hills Volcano, Montserrat, West Indies: 20052008. Geophysical Research Letters 370, L00E08. 
Samsonov, S., van der Kooij, M., Tiampo, K., 2011. A simultaneous inversion for deformation rates and topographic errors of dinsar data utilizing linear least square inversion technique. Computers \& Geosciences 37, 1083 1091.

Sigmundsson, F., Vadon, H., Massonnet, D., 1997. Readjustment of the Krafla spreading segment to crustal rifting measured by satellite radar interferometry. Geophysical Research Letters 24, 1843-1846.

Siswowidjoyo, S., Suryo, I., Yokoyama, I., 1995. Magma eruption rates of Merapi volcano, Central Java, Indonesia during one century (1890 1992). Bulletin of Volcanology 57, 111-116.

Sparks, R.S.J., Young, S.R., Barclay, J., Calder, E.S., Cole, P., Darroux, B., Davies, M.A., Druitt, T.H., Harford, C., Herd, R., James, M., Lejeune, A.M., Loughlin, S., Norton, G., Skerrit, G., Stasiuk, M.V., Stevens, N.S., Toothill, J., Wadge, G., Watts, R., 1998. Magma production and growth of the lava dome of the Soufriere Hills Volcano, Montserrat, West Indies: November 1995 to December 1997. Geophysical Research Letters 25, 34213424 .

Stevens, N., Wadge, G., Murray, J., 1999. Lava flow volume and morphology from digitised contour maps: a case study at mount etna, sicily. Geomorphology 28, $251-261$.

Stevens, N.F., Wadge, G., Williams, C.A., Morley, J.G., Muller, J., Murray, J.B., Upton, M., 2001. Surface movements of emplaced lava flows mea- 
sured by synthetic aperture radar interferometry. Journal of Geophysical Research 106, 11293-11314.

Toombs, A., Wagde, G., in review. Modeling and correction for lava flow subsidence signals detected by satellite radar interferometry. Geophysical Research Letters .

Wadge, G., 1981. The variation of magma discharge during basaltic eruptions. Journal of Volcanology and Geothermal Research 11, 139-168.

Wadge, G., Oramas Dorta, D., Cole, P.D., 2006. The magma budget of Volcán Arenal, Costa Rica from 1980 to 2004. Journal of Volcanology and Geothermal Research 157, 60-74.

Wonnacott, T. H. Wonnacott, R.J., 1990. Introductory Statistics, Fifth Edition. John Wiley \& sons.

Wooster, M.J., Kaneko, T., 1998. Satellite thermal analyses of lava dome effusion rates at Unzen Volcano, Japan. Journal of Geophysical Research 103, 20935-20948.

Wright, R., Blake, S., Harris, A.J.L., Rothery, D.A., 2001. A simple explanation for the space-based calculation of lava eruption rates. Earth and Planetary Science Letters 192, 223-233.

Wright, T.J., 2004. Constraining the Slip Distribution and Fault Geometry of the Mw 7.9, 3 November 2002, Denali Fault Earthquake with Interferometric Synthetic Aperture Radar and Global Positioning System Data. The Bulletin of the Seismological Society of America 94, 175-+. 
${ }_{642}$ Zebker, H.A., Villasensor, J., 1992. Decorrelation in interferometric radar ${ }_{643}$ echoes. IEEE Transactions on Geoscience and Remote Sensing 30, 950$644 \quad 959$.

${ }_{645}$ Zobin, V., 2002. Overview of the 19972000 activity of Volcán de Colima, 646 México. Journal of Volcanology and Geothermal Research 117, 1-19. 
- We measure topographic change $>9 \mathrm{~m}$ at a volcano with InSAR

- Approach suitable for measuring lava/pyroclastic flow compaction or landslides

- Lava thickness and extrusion rate (2000-2009) measured at Santiaguito volcano

- We make first simultaneous measurements of lava thickness and subsidence rate 
ick here to download Figure: DEM_submit1.pdf
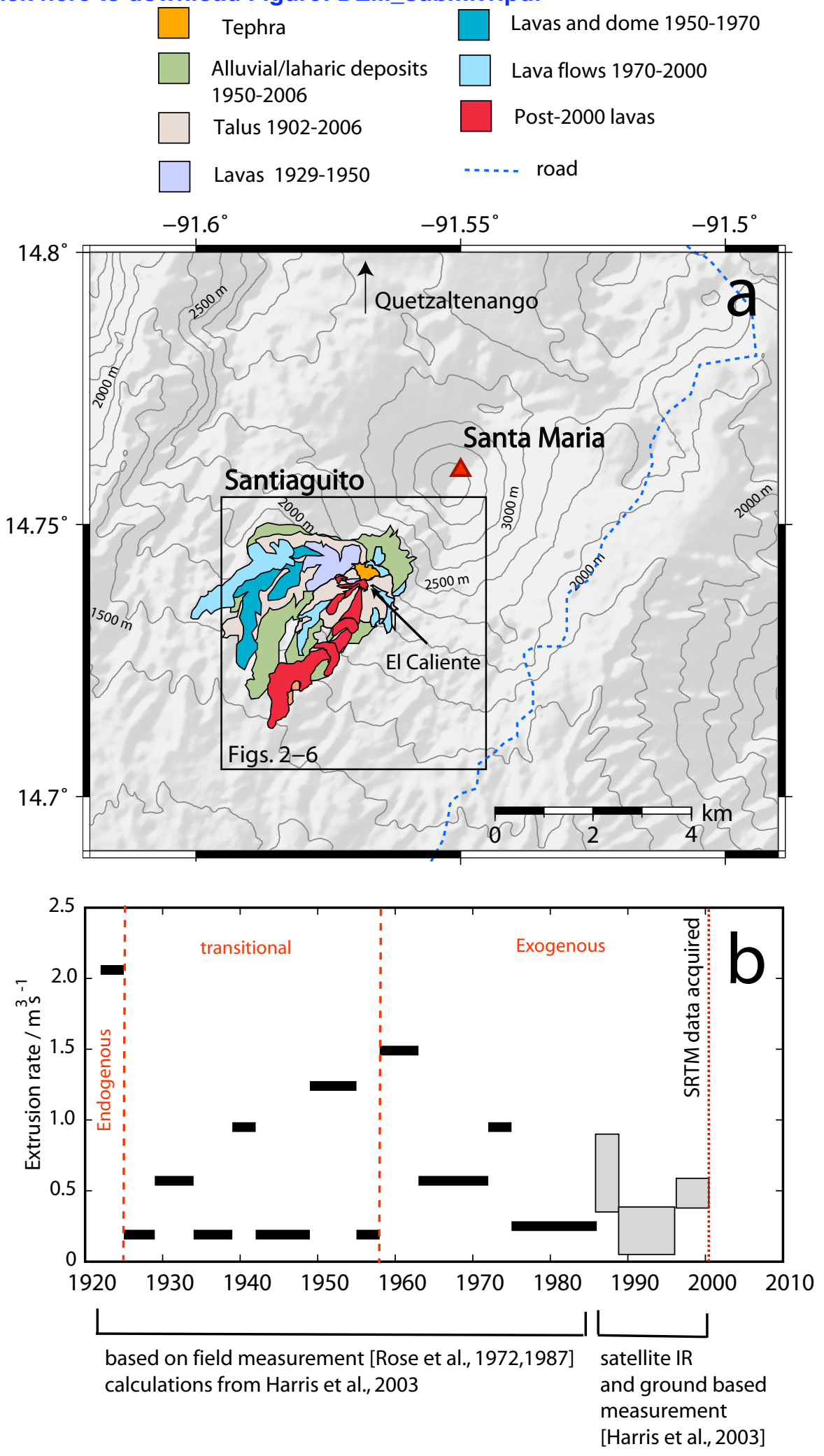

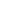

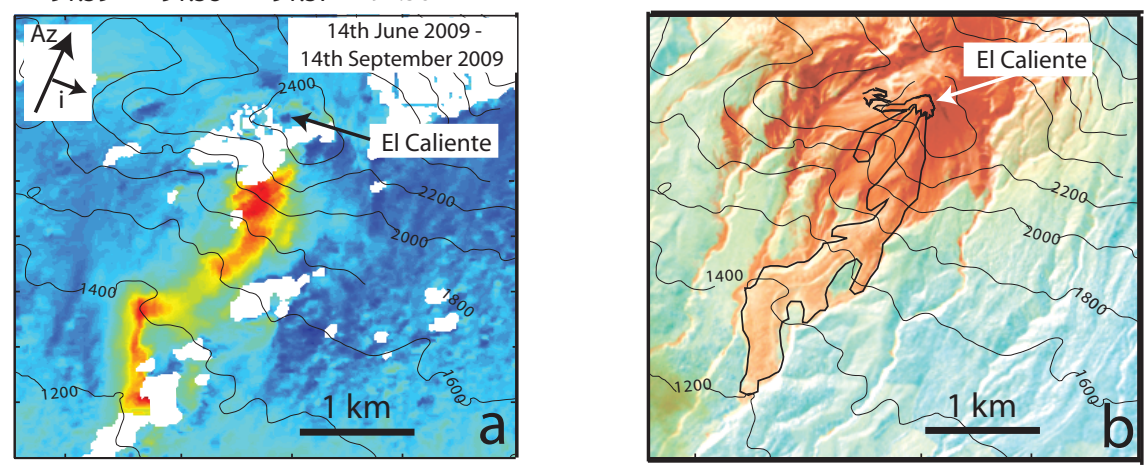

14.74

14.73

14.72

14.71

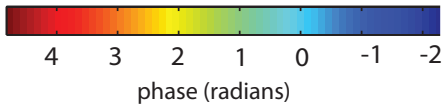

14.74

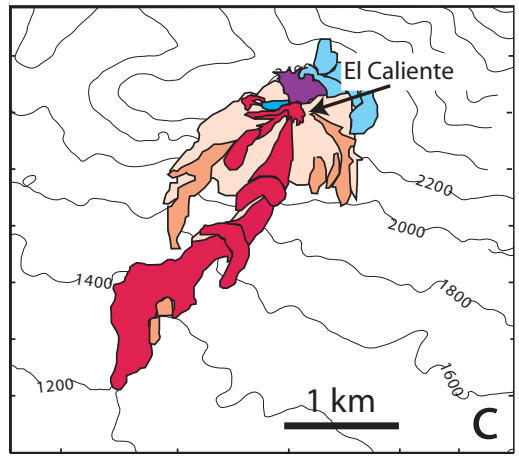

$$
\begin{array}{llll}
-91.59 & -91.58 & -91.57 & -91.56
\end{array}
$$

Lavas emplaced between 2000 and 2006

Talus 1902-2006

Lavas emplaced between 1986 and 1999

Tephra $\sim 1972-2006$

Lavas emplaced between 1972 and 1984

Lava 1929 - 1934

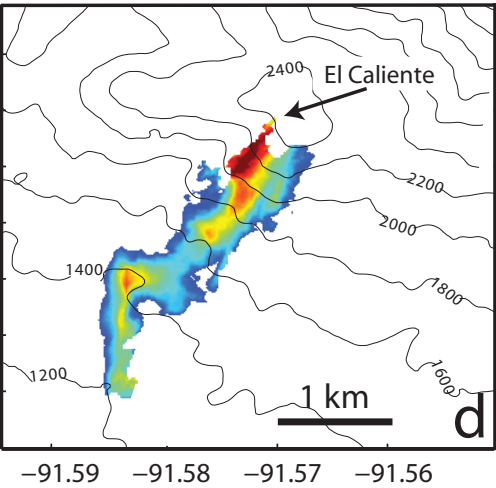

14.74

14.73

Lavas emplaced between 2000 and 2006

14.72

14.71

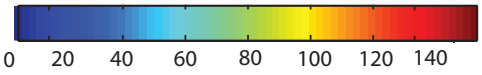

increase in lava thickness 2000 - 2007 (metres) 

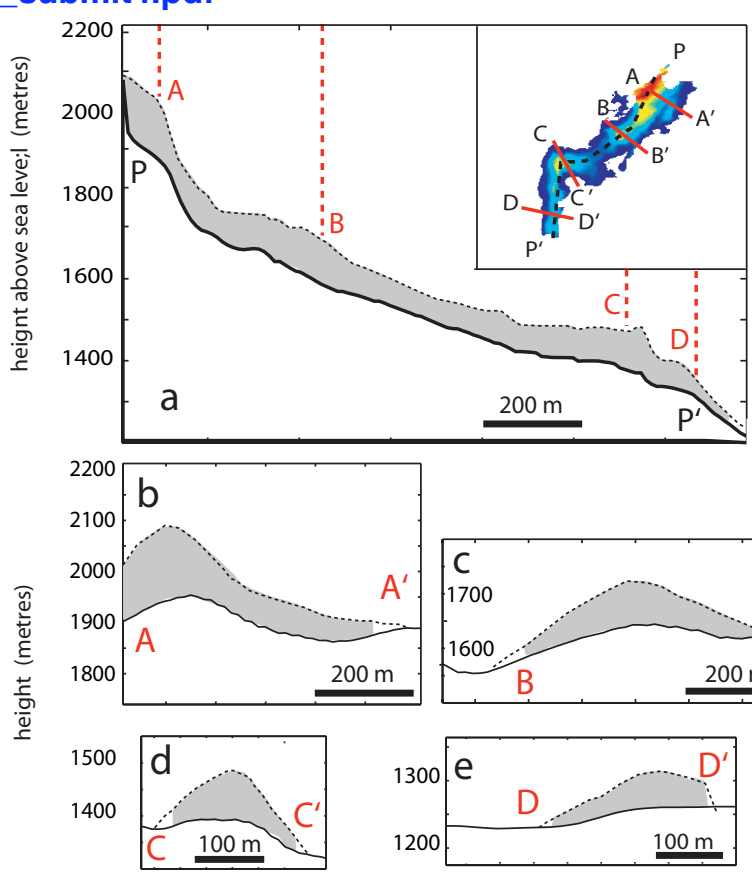


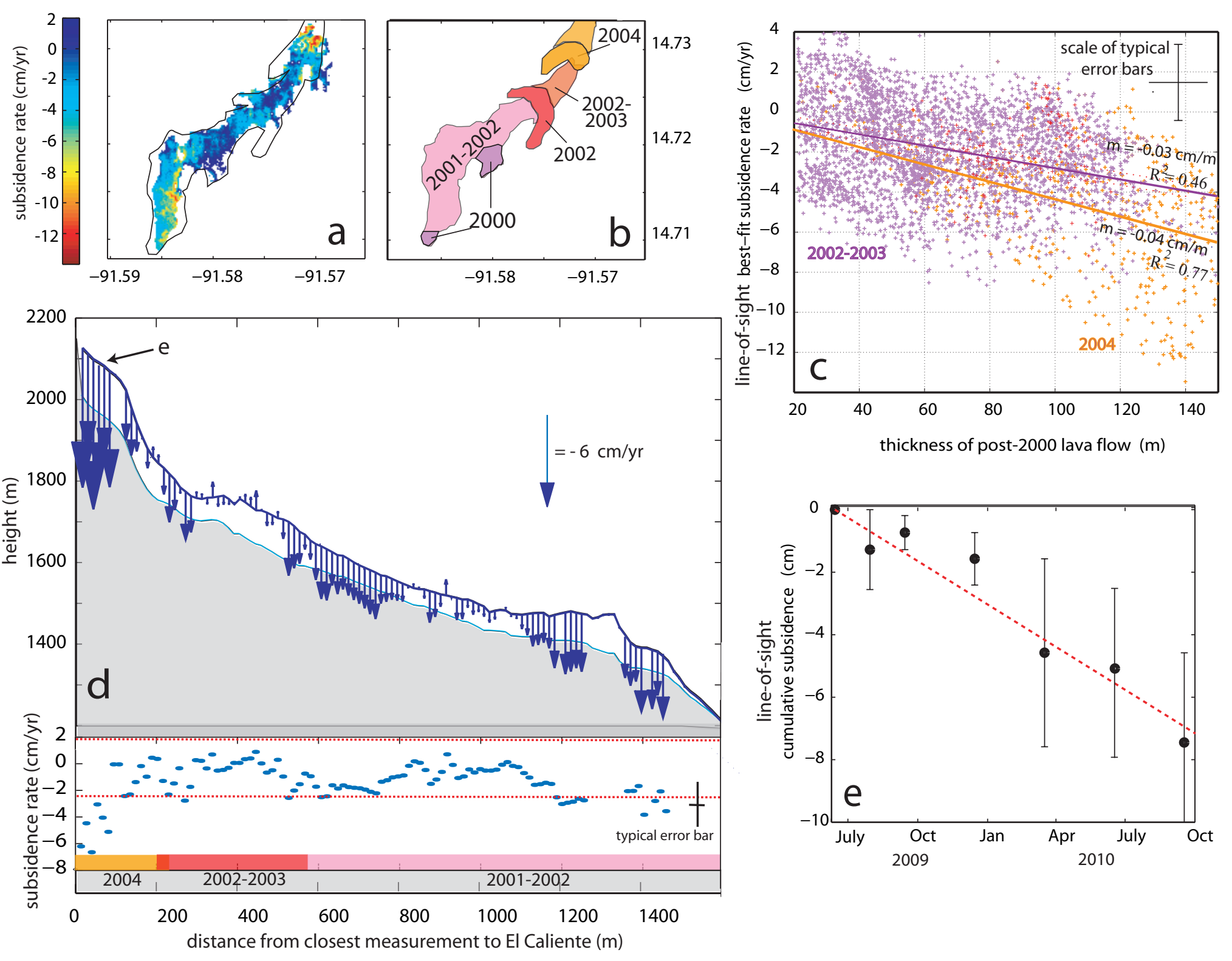



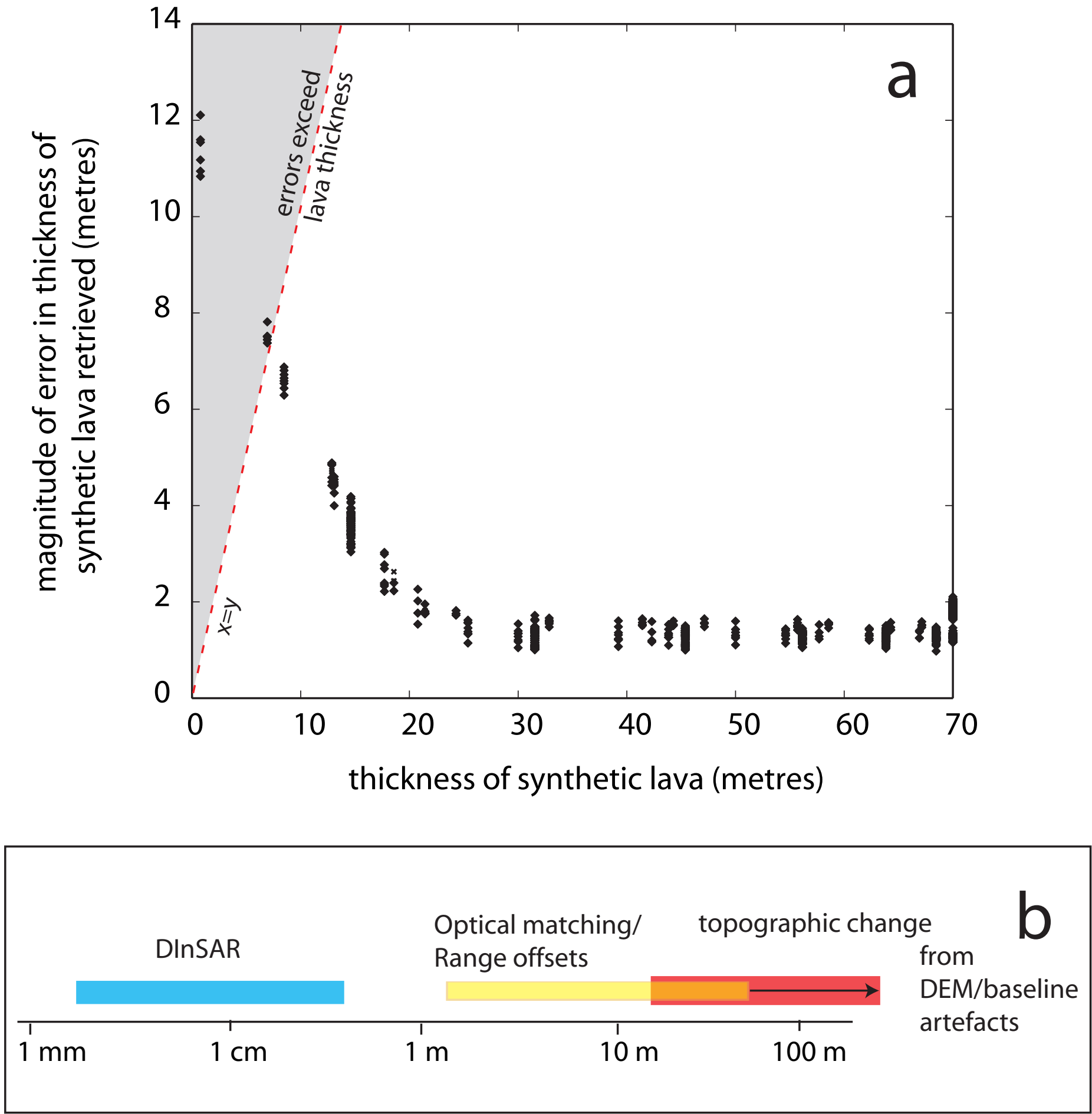